\title{
Categorization of financial assets using non- parametric DEA methods*
}

\author{
Categorización de activos financieros utilizando el método no paramétrico DEA \\ Categorização de ativos financeiros usando o método não paramétrico DEA
}

Hernán Pablo Guevel ${ }^{\text {a }}$

Universidad Nacional de Córdoba, Argentina

heguevel@unc.edu.ar

ORCID: http://orcid.org/0000-0003-4434-9178

DOI: https://doi.org/10.11144/Javeriana.cao33.cfaup

Date received: 26/08/2019

Date accepted: 16/10/2019

Date published: 20/05/2020

\begin{abstract}
:
This paper aims to propose an integrated methodological approach for the categorization of assets using the Data Envelopment Analysis (DEA, Basic Additive Model version). The need for stakeholders to assess the possibility of bankruptcy, credit risk and the creation of investment portfolios has given rise to tools capable of evaluating financial assets. Given the increasing volume of data associated with assets, categorization into groups sharing homogeneous characteristics has sometimes been chosen. This strategy implies a significant reduction in time and cost of analysis. The system selected for the analysis includes the companies that traded on the Buenos Aires Stock Exchange over the period 2009-2010.
\end{abstract}

JEL Codes: G11, G12, G19

Keywords: DEA (Data Envelopment Analysis), basic additive model, categorization, financial asset.

\section{Resumen:}

El objetivo de este artículo es proponer un enfoque metodológico integrado para la categorización de activos utilizando la metodología del Análisis Envolvente de Datos (DEA, versión Modelo Aditivo Básico). La necesidad de que los stakeholders evalúen la posibilidad de quiebra, riesgo crediticio y la confección de carteras de inversión ha dado lugar a herramientas capaces de evaluar los activos financieros. Ante el creciente volumen de datos asociados a los activos, en ocasiones se ha optado por la categorización en grupos que comparten características homogéneas. Esta estrategia implica una reducción significativa en el tiempo y el costo del análisis. El sistema seleccionado para el análisis incluye las empresas que cotizaron en la Bolsa de Buenos Aires durante el periodo 2009-2010.

Códigos JEL: G11, G12, G19

Palabras clave: DEA (Análisis Envolvente de Datos), modelo aditivo básico, categorización, activos financieros.

\section{Resumo:}

O objetivo deste artigo é propor um enfoque metodológico integrado para a categorização de ativos, utilizando a metodologia do Análise Envolvente de Dados (DEA, versão Modelo Aditivo Básico). A necessidade de que os stakeholders avaliem a possibilidade de quebra, risco creditício e a confecção de carteiras de investimento tem dado lugar a ferramentas capazes de avaliar os ativos financeiros. Perante o crescente volumem de dados associados aos ativos, em ocasiões tem se optado pela categorização em grupos que compartilham características homogéneas. Esta estratégia implica uma redução significativa do tempo e o custo da análise. O sistema selecionado para a análise inclui as empresas que cotizam na Bolsa de Buenos Aires durante o período 2009-2010.

Códigos JEL: G11, G12, G19

Palavras-chave: DEA (Análise Envolvente de Dados), modelo aditivo básico, categorização, ativos financeiros.

\section{Introduction}

Investors, banks and creditors faced with various financial decisions and they perform different types of analysis: Crisis risk analysis, business failure or bankruptcy analysis, credit risk analysis or investment

\section{Author notes}

${ }^{a}$ Corresponding author. E-mail: heguevel@unc.edu.ar 
portfolio composition analysis. To this end, since the mid-20th century, emphasis has been placed on the need to develop tools capable of assessing business vulnerability and volatility and such tools have generally drawn upon statistical methods.

Investment on financial assets has received special attention from the fields of administration, accounting and finance leading to the development of several methodologies for the construction of investment portfolios. In this regard, current doctrine proposes two types of analysis: technical and fundamental. Whereas the former is based on the study of the fluctuations in prices that generate investors' expectations, the latter focuses on determining the true value of the stock.

Technical analysis was first introduced by Dow (1884) by means of what came to be known as Dow's Theory. Later, Elliot (1938) made a major contribution to the field with his Elliot Wave Theory which had a great impact on the stock and futures markets. On the other side, fundamental analysis emerged in 1934 with the publication of Graham and Dodd's seminal book, Security Analysis (Graham, Dodd \& Cottle, 1934). They put forward techniques for valuing stocks in terms of their current and future performance. This type of analysis focus on the assessment of the intrinsic or real value of a stock, which is not always its market price.

Some years later, Portfolio Theory proposed by Markowitz (1952) held that the investor approaches the portfolio as a whole, examining risk and global return characteristics instead of choosing individual stocks in view of the expected return of each stock in particular. According to this theory, portfolio selection requires considering long-term expected return and short-term volatility. This latter is deemed as a risk factor and the portfolio is constructed based on each individual investor's tolerance for risk with the aim of weighing the maximum return for the selected level of risk.

Portfolios include, among others, financial assets that are securities representing a payment obligation which grants the buyer the right to receive future cash flows from the company and materializes into a contract. Basically, this refers to stocks, negotiable bonds, derivatives and any other similar listed securities.

Following Markowitz's theory, each item in the portfolio should be associated to a particular level of risk. In order to count with information that has been previously analyzed, there has recently emerged a trend towards categorizing financial assets into groups that generally share homogeneous characteristics. The categorization of financial assets significantly reduces the time and cost of analysis and can be incorporated into the process of constructing the investment portfolio.

At present, Doumpos \& Zopounidis (2002) and Zopounidis (1999) state that the subject of study of selection and portfolio management can be divided into three categories:

1. Studies that focus on risk and return, such as the Capital Asset Pricing Model-CAPM-developed by Sharpe (1964) and the Arbitrage Pricing Theory -APT- of Ross (1976).

2. Studies that strive for developing methodologies that would allow the evaluation of financial assets' performance. Amiri et al. (2009, 2010), propose a methodology for assessing the risk of portfolios using DEA and MDM techniques. Escobar (2015) use hybrid methods and Mashayekhi \& Omrani (2016) use fuzzy returns to create portfolios. The work by Zopounidis \& Doumpos (2013) and Spronk \& Hallerbach (1997) exemplify the efforts made in this direction.

3. Studies that focus on the development of portfolio construction methodologies, such as those by Zopounidis \& Doumpus (2013) and Xidonas, Mavrotas, Zopounidis, \& Psarras (2011).

Argentine law raises the need to regulate credit rating in order to ensure that investors have free access to information, especially small investors who usually have neither knowledge nor appropriate processing capacity. Listed below there are some important aspects arising from its regulatory code (Comisión Nacional de Valores, 2020): 
- Created by decree $656 / 92$, its goal is to provide investors with more information. It is performed by Credit Rating Agencies -CRA- which must be previously authorized by the Comisión Nacional de Valores.

- Presently, there are 9 CRAs, namely, Evaluadora Latinoamericana, Fix SCR, Moody's, Professional Rating Service, S \& P Global, Universidad de Buenos Aires, Universidad Nacional de San Martín, Universidad Nacional de Tres de Febrero and Universidad Nacional del Centro de la Provincia de Buenos Aires.

- CRAs must be corporations with independent opinion, thus they cannot be related to any accounting, law, portfolio management or consultancy firm.

- Even if this is not mandatory for the local market, it is a compulsory requirement for their trading abroad.

In this analysis we will only refer to stocks, a particular case of financial assets defined as securities representing the capital contributions made by shareholders to the issuing company. They confer the status of shareholder on its owner together with all applicable rights depending on their type (common, preferred or multiple-vote).

The aim of this paper is to propose an integrated methodological approach for the categorization of financial assets considering the multidimensional nature of the issue, using the DEA methodology.

DEA was developed by Charnes, Cooper \& Rhodes (1978) for evaluate the performance of a set of homogeneous units, Decision Making Units -DMUs-, which from the same set of inputs, generates the same set of outputs, sorting them in terms of their "efficiency relative". These methods determine a frontier of best practices, on which efficient units are located. A variable is considered an "Input" when, keeping the values of all other indicators constant, efficiency decreases if its value increases, and is considered an "Output", when it increases the efficiency of DMUs by increasing their value, staying values of the remaining ones (Alberto et al., 2000).

DEA methods offer the following advantages: multiples inputs and outputs need not be related; they generate individual efficiency performance compared with the group under study; they allow to evaluate efficiency taking into account the economies of scale of each DMU; they make it possible to suggest courses of action through the benchmarking proposed by the method and finally, they do not need a large number of DMUs to achieve satisfactory results.

The system selected for analysis comprises are the companies listed on the Buenos Aires Stock Exchange. Based on the information gathered, listed companies are 82 . The system analyzed in this paper excludes (a) financial and insurance companies which are ruled by specific regulations, (b) all companies for which we lack information or whose information is unreliable for the period under analysis, and (c) "troubled" companies that meet the criteria specified by the Buenos Aires Stock Exchange. ${ }^{[1]}$ Only the companies that traded over the period 2009-2010 whose financial statements were properly published through the Comisión Nacional de Valores (controller agency) were included in the analyzed sample. Considering the limitations listed above, the population under study is 44 companies.

It is important to point out that the financial statements under analysis have been duly audited under conditions specified by the controller agency, thus allowing for the conceptual standardization with the aim of making comparisons between them.

\section{Data envelopment analysis model}

Since 1978 a wide range of DEA variants have been developed, particularly in this paper Basic Additive Model is used (Charnes et al., 1985; Banker, Charnes, \& Cooper, 1984). The selected DEA model has some features which make it suitable for this particular application case. First, it can be used against input 
or output deficits. Second, being independent of the measurement units, it allows using any criterion that is considered applicable. Third, it allows scaling the data without creating distortions in measurements (translation invariance) thus providing a solution to the problem of negative observations that often occur in income statements. Finally, it makes it possible to consider DMUs' scale economies.

Assuming a set of $n$ companies, the performance of each $\operatorname{DMU}_{j}(j=1,2, \ldots, n)$ will be the result of $m$ inputs and $s$ outputs. We define set $\mathrm{X}$ and set $\mathrm{Y}$. The former is made up of $\mathrm{x}_{\mathrm{ij}}(\mathrm{i}=1,2, \ldots, \mathrm{m})$ which represents the value input $\mathrm{i}$ takes for the $\mathrm{DMU}_{\mathrm{j}}$. Similarly, each item in set $\mathrm{Y}$, represented by $\mathrm{y}_{\mathrm{rj}}(\mathrm{r}=1,2, \ldots, \mathrm{s})$, represents the value that output $r$ takes for the $\mathrm{DMU}_{\mathrm{j}}$.

We include below the Basic Additive Model for $\mathrm{DMU}_{\mathrm{o}}$ (the DMU being evaluated relative to the performance of the others DMU).

$$
\begin{aligned}
& \operatorname{Max} z=\sum_{\mathrm{i}=1}^{m} S_{\mathrm{io}}^{-}+\sum_{\mathrm{r}=1}^{s} S_{\mathrm{ro}}^{+} \\
& s a \\
& \sum_{\substack{\mathrm{i}=1 \\
n}}^{n} \lambda_{j} x_{\mathrm{ij}}+\mathrm{S}_{\mathrm{io}}^{-}=\mathrm{x}_{\mathrm{io}} \\
& \sum_{\mathrm{i}=1}^{n} \lambda_{j} y_{\mathrm{rj}} \mathrm{S}_{\mathrm{ro}}^{+}=\mathrm{y}_{\mathrm{ro}} \\
& \sum_{\mathrm{i}=1}^{n} \lambda_{j}=1 \\
& \lambda_{j} ; \mathrm{S}_{\mathrm{io}}^{-} ; \mathrm{S}_{\mathrm{ro}}^{+} \geq 0, \\
& \mathrm{j}=\{1,2, \ldots, \mathrm{n}\}, \mathrm{i}=\{1,2, \ldots, \mathrm{m}\}, \mathrm{r}=\{1,2, \ldots, \mathrm{s}\}
\end{aligned}
$$

[Equation 1]

Where:

$S_{\text {io }}^{-}$and $S^{+}$io represent the value taken by the slack variable of each input and output for the $\mathrm{DMU}_{\mathrm{o}}$. $\lambda_{\mathrm{j}}$ is the $\mathrm{DMU}_{\mathrm{o}}$ intensity vector and represents the association of the DMU under study and the ith DMU.

The objective in (1) is directed to maximizing the distance as measured by the sum of the input plus output slacks. This distance is called the "city-block" metric.

According to the formulation of the problem, if the sum of the slacks is zero, the DMU will be efficient the unit under analysis is located on the frontier of best practices. Moreover, each nonzero slack identifies an inefficient amount in the corresponding input or output for DMU measured.

In addition, each slack provides information on the intensity of inefficiency of each DMU. It can be used, for example, to determine courses of action for improvement.

It should be pointed out that the model at $(1)$ is the Basic Additive Model with variable returns to scale VRS-. If the equality restriction of $\lambda_{j}$ is omitted the model becomes a Basic Additive Model with constant returns to scale-CCR-.

In broad terms, for DEA models to be used there should be a relationship between inputs/outputs, which is called degrees of freedom. Although the available literature provides several proposals, this work follows the rule of thumb proposed by Cooper, Seiford, \& Tone, (2000): $\mathrm{n} \geq \max \{\mathrm{mxs}, 3(\mathrm{~m}+\mathrm{s})\}$. From this formula, it follows that the larger is the number of inputs/outputs to be considered, the larger the number of DMUs under consideration. 


\section{Methodology proposed for asset classification}

The methodology proposed in this paper is based on the creation of a $\mathrm{L}$ set of categories consisting of $\left(\mathrm{L}_{1}, \mathrm{~L}_{2}\right.$, ...., $\mathrm{L}_{\mathrm{N}}$ ), defining $\mathrm{L}_{1}$ as the most desirable category and $\mathrm{L}_{\mathrm{N}}$ as the least desirable category.

Once categories are created, the $\mathrm{n}$ DMUs need to be labelled following this procedure:

Step 1:

- Analyze whether the number of DMUs is in compliance with the degrees of freedom rule of thumb proposed by Cooper et al. (2000) stated in (2).

- Evaluate the efficiency of the group with the VRS Basic Additive Model.

- Efficient units are regarded as $\mathrm{L}_{1}$ category.

- Segregate inefficiencies and move to Step 2.

Step 2:

- Reevaluate uncategorized units from Step 1.

- Analyze whether the remaining number of DMUs is in compliance with the degrees of freedom rule of thumb proposed by Cooper et al. (2000) stated in (2).

- Evaluate the efficiency of the group with the VRS Basic Additive Model.

- Efficient units are regarded as $\mathrm{L}_{\mathrm{i}+1}$ category.

- Segregate inefficiencies and repeat de process until formula (2) does no longer apply and consider the inefficient DMUs as a last category $(\mathrm{N})$.

The following chart illustrates the proposed procedure based on the steps described above.

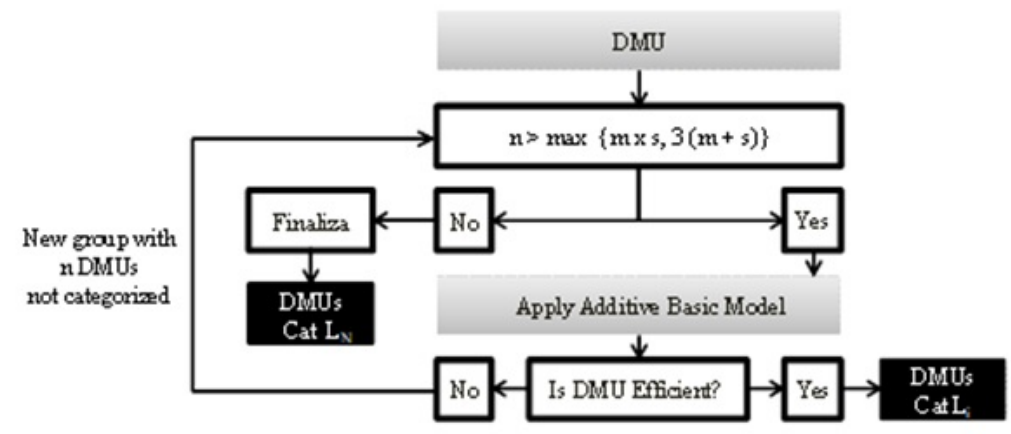

FIGURE 1

Flow chart of the proposed procedure Source: Own elaboration.

Dealing with DEA models and their characteristics requires a computational tool for evaluation. In this case, we have written a special code in " $\mathrm{R}$ " software using different libraries. The more important are "Benchmarking" and "nonparaeff".

\section{Application to the financial assets listed on the buenos aires stock exchange}

To analyze the performance of the companies in the Buenos Aires Stock Exchange, before we must select attributes that reflect the economic and financial situation of each company. Zopounidis \& Doumpos (1999) state that the selection of attributes should be made according to the following criteria: availability of the data, relevance of the information and expert opinion. 
Financial statements include relevant information as to business performance, based on the criteria followed by Caro (2013) who drawing upon the work done by Altman (1968), Altman \& Hotchkiss (1993) and Jones \& Hensher (2004), suggests using short-term solvency measures, long-term indebtedness, liquidity, operational cycle and profitability.

Short-term solvency measures are the first dimension to consider. Even if there are various ways to evaluate a company's short-term liquidity, the authors propose to use the assets with greater liquidity (liquid assets: LA) which we define as cash and investments that can be turned into cash within 24 hours.

The second dimension is the level of long-term indebtedness, represented by the relation between debt $-\mathrm{D}$ - and net worth -NW-, that is, the commitment of economic resources to the company. The debt represents the amount of currency invested by third-parties while net worth is the amount of currency invested by shareholders. Any ratio including these concepts would be of difficult application as it would be desirable at some ranges and undesirable at some others. We thus propose treating its components separately.

The third dimension, liquidity, is evaluated by means of the cash flow - CF- which represents the company's flow of money.

The operational cycle dimension will be evaluated through sales -S- and working capital -WC-, being the former the company's volume of business and the latter the amount of money used for business activities, measured by the difference between current assets -CA- and current liabilities -CL-.

Finally, profitability, the fifth dimension, can be evaluated through profit, particularly profit before interest and taxes (operating expenses: $\mathrm{OE}$ ).

These measures will be considered for efficiency evaluation based on the definitions provided. Some measures are considered to be more desirable the higher their value, while others are regarded more desirable the lower their value. In this case, the ratios that need to be minimized will be input $-\mathrm{D}, \mathrm{NW}-$ and the ratios that need to be maximized will be output -CF, LA, S, WC, OE-.

\section{Application - Year 2010}

The table 1 shows the descriptive measures used for inputs and outputs in the proposed categorization.

TABLE 1

Descriptive measures of inputs and outputs, year 2010

\begin{tabular}{|c|c|c|c|c|c|c|c|}
\hline & $L A$ & $D$ & $N W$ & $C F$ & $S$ & $W C$ & $O E$ \\
\hline Mean & $3.53 \mathrm{E}^{-09}$ & $1.34 \mathrm{E}^{-09}$ & $1.50 \mathrm{E}^{-09}$ & $4.68 \mathrm{E}^{-10}$ & $2.23 \mathrm{E}^{-11}$ & $-6.97 \mathrm{E}^{-09}$ & $9.10 \mathrm{E}^{-09}$ \\
\hline Median & $1.14 \mathrm{E}^{+09}$ & $3.94 \mathrm{E}^{-08}$ & $5.35 \mathrm{E}^{-08}$ & $5.30 \mathrm{E}^{+09}$ & $4.94 \mathrm{E}^{+10}$ & $2.18 \mathrm{E}^{+09}$ & $4.77 \mathrm{E}^{-08}$ \\
\hline Stan. Desv. & $8.07 \mathrm{E}^{-09}$ & $3.87 \mathrm{E}^{-09}$ & $3.21 \mathrm{E}^{-09}$ & $1.98 \mathrm{E}^{-11}$ & $6.27 \mathrm{E}^{-11}$ & $9.27 \mathrm{E}^{-10}$ & $3.45 \mathrm{E}^{-10}$ \\
\hline Range & $4.70 \mathrm{E}^{-10}$ & $2.56 \mathrm{E}^{-10}$ & $1.90 \mathrm{E}^{-10}$ & $1.32 \mathrm{E}^{+12}$ & $4.05 \mathrm{E}^{+12}$ & $7.52 \mathrm{E}^{-11}$ & $2.15 \mathrm{E}^{-11}$ \\
\hline Minimum & $1.03 \mathrm{E}^{-07}$ & $6.96 \mathrm{E}^{-06}$ & $1.56 \mathrm{E}^{-07}$ & $-9.82 \mathrm{E}^{+09}$ & $3.02 \mathrm{E}^{-09}$ & $-5.07 \mathrm{E}^{-11}$ & $-1.39 \mathrm{E}^{-10}$ \\
\hline Maximum & $4.70 \mathrm{E}^{+10}$ & $2.56 \mathrm{E}^{-10}$ & $1.90 \mathrm{E}^{-10}$ & $1.31 \mathrm{E}^{+12}$ & $4.05 \mathrm{E}^{-12}$ & $2.45 \mathrm{E}^{-11}$ & $2.01 \mathrm{E}^{+11}$ \\
\hline C.V. & 2.28 & 2.90 & 2.14 & 4.22 & 2.81 & -13.3 & 3.79 \\
\hline
\end{tabular}

Source: Own elaboration.

The difference between the mean and the median and the wide range between the maximum and the minimum value for each criterion supposes a great dispersion of the data, showing the presence of outlier values. In addition, three of the selected criteria, namely, CF, WC and OE, have negative values. On this account, we recommend using the Basic Additive Model which allows scaling the data without distortions.

The flowchart in Figure 2 outlines the procedure performed for the 44 DMUs. 16 companies are deemed as the best DMUs, 15 belong to category $\mathrm{B}$ and the remaining 13 are category $\mathrm{C}$. About the process and time of performing computational calculations. The dimension of the process, in the first step, has 44 linear programing problems with 52 variables and 9 restrictions and the reevaluation process has 28 linear programing problems with 36 variables and 9 restrictions. The whole estimation process took less than 1 second. 


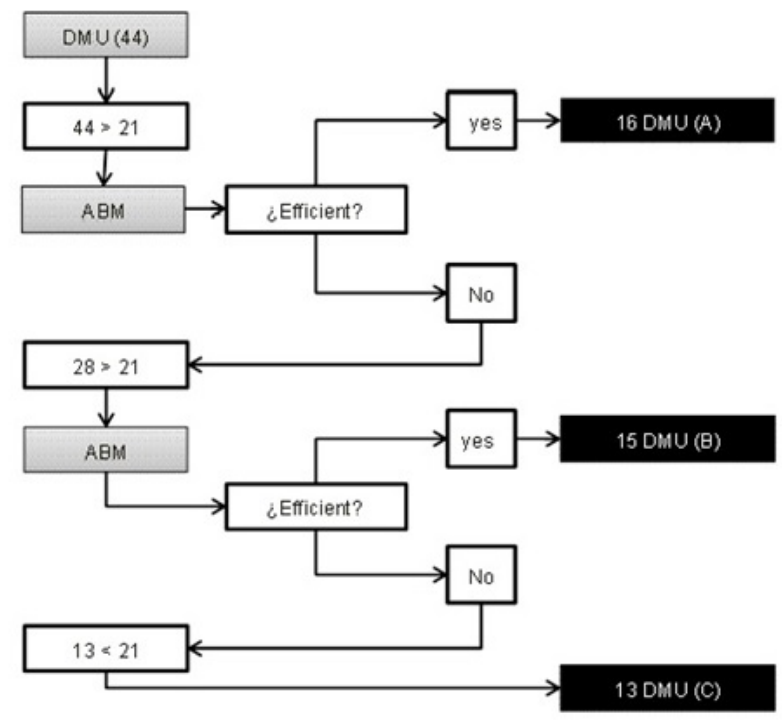

FIGURE 2

Categorization procedure for the 44 DMUs, year 2010

Source: Own elaboration.

Table 2 shows performance indexes of the 44 DMUs ordered on the basis of their performance: a) lists the 16 DMUs belonging to category A; b) shows the 15 companies considered to be category $\mathrm{B}$ and their performance in relation to category A; and finally $1 \mathrm{c}$ ) includes the remaining 13 companies considered to be category $\mathrm{C}$ together with their performance in relation to category $\mathrm{A}$ and $\mathrm{B}$.

TABLE 2

Categorization resulting from the methodology described in section 3, year 2010
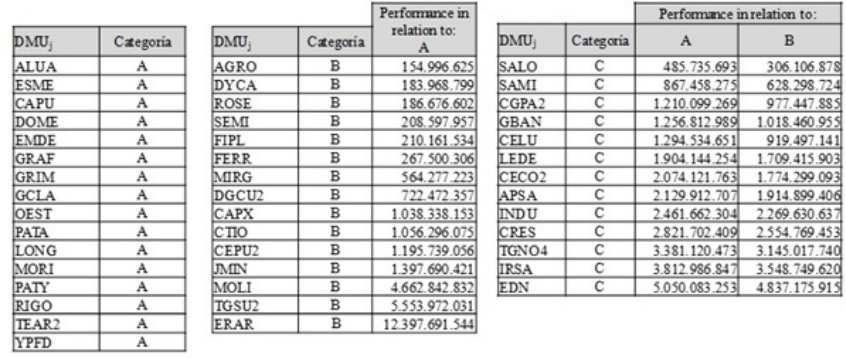

Source: Own elaboration.

The analysis of the categories allows us to recognize the following general characteristics: companies belonging to category $\mathrm{A}$ are strong in their ratios related to economic activity and possess a relatively strong short-term financial position. The relationship between debt and net worth is not determinant. Companies categorized as B are companies showing strength in the ratios related to economic activity and a rather ambiguous short-term financial position. Finally, companies categorized $\mathrm{C}$, are companies showing weakness in the ratios related to economic activity both in their results and business performance.

Based on the result achieved for each company, categorization also allows the identification of a course of action to improve its category, for example:

DYCA (company categorized as B with a performance of 183.968.799), the slack vector is [D, NW, CF, LA, S, WC, OE $]=[160.243 .206,3.723 .059,0,1.899 .388,3.799 .105,14.329 .039,0]$, which means it should decrease D by $73 \%$ and NW by $2 \%$ and increase the LA, S, and WC ratios by $62 \%, 3 \%$ y $19 \%$ respectively to move from category B to category A. Its referent DMUs will be RIGO (0.46); DOME (0.45); OEST (0.09).

On the other hand, SALO illustrates the case of a group of companies categorized as $\mathrm{C}$ which face two possible courses of action: it can aspire to be category A or B. If wanting to be A, it should increase CF, LA, 
S, WC and OE by $30 \%, 111 \%, 78 \%, 92 \%$ y $55 \%$ respectively, and decrease D by $96 \%$ and NW by $91 \%$, its referent is GRAF. If wanting to be category $\mathrm{B}$, it should reduce D by $76 \%$ and NW by $73 \%$ as well as increase CF, LA, and WC by 6\%, 160\% y $81 \%$ respectively. Its referent DMUs will be AGRO (0.49); ROSE (0.49); $\operatorname{SEMI}(0.02)$.

\section{Incorporating the trend to 2010 categorization}

Following the same working methodology and with the purpose of providing more and better information to the decision maker, we incorporated the categories from the previous year (2009) and obtained 22 category A, 16 category B and 6 category C DMUs, as shown in Table 3.

TABLE 3

Categorization resulting from the methodology described in section 3, year 2009

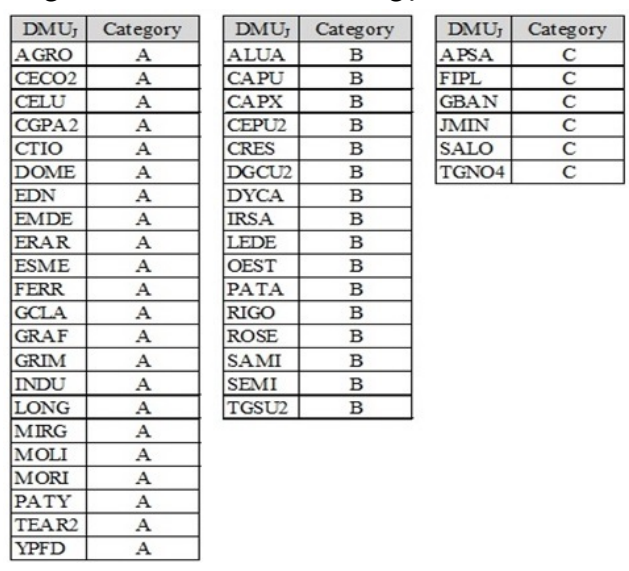

Source: Own elaboration.

Table 4 shows the comparison of categorized DMUs between the year 2009 and 2010. It can be observed that a group of companies improved their performance, namely, ALUA, CAPU, OEST, PATA, RIGO,JMIN and FIPL. Another group of companies worsened their performance: MIRG, FERR, AGRO, MOLI, CTIO, ERAR, CECO2, CELU, CGPA2, EDN, INDU, LEDE, SAMI, CRES and IRSA. Finally, the group of companies that kept their category includes all the DMUs not mentioned above.

TABLE 4

Comparison of the proposed categorization for 2010 and 2009 respectively
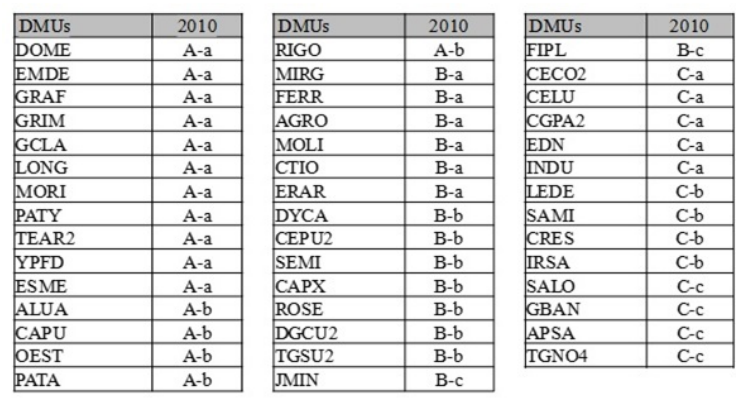

Source: Own elaboration.

Table 5 describes category performance compared to that of the previous year. Companies on the main diagonal kept the same category over the two-year period analyzed and account for $50 \%$. On the upper 
triangular matrix, we can see companies that improved their rating and account for $16 \%$. Finally, on the lower triangular matrix we find companies that worsen their situation and represent $34 \%$.

TABLE 5

2009-2010 comparison of the DMUs under analysis

\begin{tabular}{|c|c|c|c|c|}
\cline { 3 - 5 } \multicolumn{2}{c|}{} & \multicolumn{3}{c|}{ Categ ory 2009} \\
\cline { 3 - 5 } \multicolumn{2}{c|}{} & a & b & c \\
\hline \multirow{2}{*}{$\begin{array}{c}\text { Categ ory } \\
2010\end{array}$} & A & $25 \%$ & $11 \%$ & $0 \%$ \\
\cline { 2 - 5 } & B & $14 \%$ & $16 \%$ & $5 \%$ \\
\cline { 2 - 5 } & C & $11 \%$ & $9 \%$ & $9 \%$ \\
\hline
\end{tabular}

Source: Own elaboration.

\section{Final remarks}

This work applied DEA for the categorization of companies listed on the Buenos Aires Stock Exchange with the aim of proposing a categorization capable of providing decision makers with previously analyzed information at the moment of trading securities.

In line with the stated objective, we were able to segregate the companies in three categories and, on the basis of their efficiency performance over 2009 and 2010; we incorporated the concept of trend into the proposed classification.

The procedure proposed in this paper makes it possible to determine general characteristics for each cluster and offers a tool for the determination of courses of action towards business improvement, such is the case of the benchmarking done in the last section.

Lastly, this study has proven that the Basic Additive Model is suitable for the categorization of financial assets. The results obtained encourage us to continue our research by introducing fuzzy variables to the methodological development carried out, applying it to decision-making models, particularly oriented to the making of long-term investment portfolios.

\section{REFERENCES}

Alberto, C., Pérez, C., Carignano, C., \& Funes, M. (2000). Evaluación de la eficiencia en investigación científica y desarrollo experimental en países Iberoamericanos. Publicado en Anales del X CLAIO. México D.F.

Altman, E. I. (1968). Financial ratios, discriminant analysis and the prediction of corporate bankruptcy. The Journal of Finance, 23(4), 589-609. https://doi.org/10.1111/j.1540-6261.1968.tb00843.x

Altman, E. I., \& Hotchkiss, E. (1993). Corporate financial distress and bankruptcy. New Jersey: John Wiley \& Sons, Inc., Hoboken.

Amiri, M., Zandieh, M., Soltani, R., \& Vahdani, B. (2009). A hybrid multi-criteria decision-making model for firms competence evaluation. Expert Systems with Applications, 36(10), 12314-12322. https://doi.org/10.1016/j.esw a.2009.04.045

Amiri, M., Zandieh, M., Vahdani, B., Soltani, R., \& Roshanaei, V. (2010). An integrated eigenvector -DEA- TOPSIS methodology for portfolio risk evaluation in the FOREX spot market. Expert Systems with Applications, 37(1), 509-516. https://doi.org/10.1016/j.eswa.2009.05.041

Banker, R., Charnes, A., \& Cooper, W. (1984). Some models for estimating technical and scale inefficiencies in data envelopment analysis. Management science, 30(9), 1078-1092. https://doi.org/10.1287/mnsc.30.9.1078

Caro, N. P. (2013). Evaluación de riesgo de crisis financiera en empresas argentinas en los periodos 1993-2000 y 2003-2010. Tesis de Doctorado en Ciencias Económicas, Universidad Nacional de Córdoba, Córdoba. http:// hdl.handle.net/11086/712 
Charnes, A., Cooper, W., \& Rhodes, E. (1978). Measuring the efficiency of decision making units. European Journal of Operational Research, 2(6), 429-444. https://doi.org/10.1016/0377-2217(78)90138-8

Charnes, A., Cooper, W., Golany, B., Seiford, L., \& Stutz, J. (1985). Foundations of data envelopment analysis for Pareto-Koopmans efficient empirical production functions. Journal of Econometrics, 30(1-2), 91-107. https://d oi.org/10.1016/0304-4076(85)90133-2

Comisión Nacional de Valores (2020). Calificadoras de Riesgos. Recovered January 10, 2020, https://www.argentina .gob.ar/normativa/recurso/67292/res368-11-6-2001cap16/htm.

Cooper, W., Seiford, L., \& Tone, K. (2000). Data envelopment analysis. In W. Cooper, L. Seiford, \& J. Zhu (eds.), Handbook on Data Envelopment Analysis (pp. 1-40), 1st ed. https://doi.org/10.1007/1-4020-7798-X_1

Doumpos, M., \& Zopounidis, C. (2002). Multicriteria decision aid classification methods, v. 73. Springer Science \& Business Media. https://doi.org/10.1007/b101986

Dow, C. H. (1884). Dows theory. Wall Street Journal. News paper. Online consultation.

Elliot, R. N. (1938). The wave principle. Alanpuri Trading. Publishers of rare stock market books. https://www.alan puritrading.com/shop/stock-market-psychology/r-n-elliott-3-volume-set-wave-principle-1938

Escobar, J. (2015). Metodología para la toma de decisiones de inversión en portafolio de acciones utilizando la técnica multicriterio AHP. Contaduria y administración, 60(2), 346-366. https://doi.org/10.1016/S0186-1042(15)30 004-8

Graham, B., Dodd, D., \& Cottle, S. (1934). Security analysis (pp. 44-45). New York: McGraw-Hill.

Jones, S., \& Hensher, D. (2004). Predicting firm financial distress: A mixed logit model. The Accounting Review, 79(4), https://doi.org/10.2308/accr.2004.79.4.1011

Markowitz, H. (1952). Portfolio selection. Journal of Finance, 7(1), 77-91. https://doi.org/10.1111/j.1540-6261.19 52.tb01525.x

Mashayekhi, Z., \& Omrani, H. (2016). An integrated multi-objective Markowitz-DEA cross-efficiency model with fuzzy returns for portfolio selection problem. Applied Soft Computing, 38, 1-9. https://doi.org/10.1016/j.asoc .2015.09.018

Ross S. (1976). The arbitrage theory of capital asset pricing. Journal of Economic Theory, 13(3), 341-360. https://doi .org/10.1016/0022-0531(76)90046-6

Sharpe, W. F. (1964). Capital asset prices: A theory of market equilibrium under conditions of risk. Journal of Finance, 19(3), 425-442. http://efinance.org.cn/cn/fm/Capital\%20Asset\%20Prices\%20A\%20Theory\%20of\%20Mark et\%20Equilibrium\%20under\%20Conditions\%20of\%20Risk.pdf

Spronk, J., \& Hallerbach, W. (1997). Financial modelling: Where to go? With an illustration for portfolio management. European Journal of Operational Research, 99(1), 113-125. https://doi.org/10.1016/S0377-2217 (96)00386-4

Xidonas, P., Mavrotas, G., Zopounidis, C., \& Psarras, J. (2011). IPSSIS: An integrated multicriteria decision support system for equity portfolio construction and selection. European Journal of Operational Research, 210(2), 398-409. https://doi.org/10.1016/j.ejor.2010.08.028

Zopounidis, C. (1999). Multicriteria decision aid in financial management. European Journal of Operational Research, 119(2), 404-415. https://doi.org/10.1016/S0377-2217(99)00142-3

Zopounidis, C., \& Doumpos, M. (1999). A multicriteria decision aid methodology for sorting decision problems: The case of financial distress. Computational Economics, 14(3), 197-218. https://doi.org/10.1023/A:10087138238 12

Zopounidis, C., \& Doumpos, M. (2013). Intelligent decision aiding systems based on multiple criteria for financial engineering, v. 38. Springer Science \& Business Media. https://doi.org/10.1007/978-1-4615-4663-4

\section{Notes}

* Research paper. 
[1] A company is regarded as a "troubled" company when it is in default of payments or has called the meeting of creditors, or when the company's losses have absorbed unallocated earnings and/or a portion of shareholder's equity.

\section{Licencia Creative Commons CC BY 4.0}

Cited as: Guevel, H. P. (2020). Categorization of financial assets using non- parametric DEA methods. Cuadernos de Administración, 33. https://doi.org/10.11144/Javeriana.cao33.cfaup 